\title{
Improving The Employee Performance Through Spiritual Commitment
}

\author{
Rina Masruroh ${ }^{1}$, Tjutju Yuniarsih ${ }^{2}$, Disman $^{3}$, Budi Santoso ${ }^{4}$ \\ Universitas Kuningan, Indonesia ${ }^{1}$, Universitas Pendidikan Indonesia, Indonesia ${ }^{234}$ \\ \{rinamasruroh@student.upi.edu ${ }^{1}$, yuniarsih@upi.edu ${ }^{2}$, disman@upi.edu ${ }^{3}$, budisantoso@upi.edu ${ }^{4}$ \}
}

\begin{abstract}
Employees as part of human resources are the main determining factor for organizational success. Through optimal employee performance, the organization will develop faster and better. Commitment is believed to be a form of employee attachment to the organization that can optimize its performance. This study seeks to reveal the extent of spiritual factors in shaping employee commitment to the organization. This research was conducted on employees of a Regional owned enterprises (also known as BUMD) company in Kuningan Regency. The results show that spiritual commitment has the greatest influence over affective commitment, continuous commitment, and normative commitment.
\end{abstract}

Keywords: affective commitment; continuous commitment; normative commitment; spiritual commitment; employee performance

\section{Introduction}

The role of human resource in determining the success of organizational performance cannot be ignored because the organizational performance is mainly determined by the human resources' performance. Performance is a function of all the components of human resources, so that the management of human reseource will determine the performance achieved by the organization. (Konovsky and Pugh, 1994). To achieve superior human resource performance, human resource commitment is needed for the job and the company. Organizational commitment is the degree to which an employee sides with the organization, and the extent to which his goals and desires to maintain membership in the organization (Robbins, 2008). Employees with high commitment will show high performance as well.

According to Steers (1977), commitment is influenced by 3 main factors, namely personal character (Personal characteristics, Need for achievement, age, education), job characteristics (Task Identity, optional interaction, feedback), work characteristics (group attitude, organizational dependability, personal importance), Schemerson, et al (2011) argue that there are two main dimensions of organizational commitment, namely rational commitment (the job of providing services to individual financial, development and professional interests), and emotional commitment (what a person does is important, valuable, and provides benefits. real to others).

There are three components of the organizational commitment model according to Meyer, et al, 1991; Luthans et al, 2011; and Newstrom, 2011, namely affective commitment (feelings of friendship, corporate climate and culture, and feelings of pleasure when completing work tasks), continuance commitment (salaries, benefits, promotions, time, effort, and economic and social losses that will occur when employees leave. company), normative commitment 
(feeling indebted to superiors, colleagues or a larger company. From the various theories and commitment's approaches that have been expressed, it can be seen that no spiritual / divine component underlies commitment. This is very different from the Islamic view which considers that one's commitment is reflected in every activity undertaken.

Table 1. 2019 Employee Performance Assessment Report BUMD XXX Kuningan Regency

\begin{tabular}{|c|c|c|c|c|c|c|c|}
\hline \multirow{2}{*}{ No } & \multirow{2}{*}{ Division } & \multicolumn{5}{|c|}{ Performance assessment } & \multirow{2}{*}{$\begin{array}{c}\text { Average } \\
\text { Performance } \\
\text { Per Division } \\
\end{array}$} \\
\hline & & Integrity & Loyalty & Dedication & $\begin{array}{c}\text { Work } \\
\text { Performance }\end{array}$ & collaboration & \\
\hline 1 & public & 72 & 73 & 72 & 72 & 72 & 72,2 \\
\hline 2 & Finance & 75 & 75 & 75 & 75 & 75 & 75 \\
\hline 3 & SPI & 75 & 75 & 75 & 75 & 75 & 75 \\
\hline 4 & Service & 73 & 74 & 73 & 73 & 73 & 73,2 \\
\hline 5 & Litbang & 71 & 72 & 71 & 71 & 71 & 71,2 \\
\hline 6 & Trandis & 72 & 73 & 72 & 72 & 72 & 72,2 \\
\hline 7 & Production & 70 & 71 & 70 & 70 & 70 & 70,2 \\
\hline 8 & NRW & 70 & 71 & 70 & 70 & 70 & 70,2 \\
\hline
\end{tabular}

Based on this, this study provides an analysis of organizational commitment with a spiritual approach through the concepts of trust and sincerity. The research was conducted on employees of a Regional owned enterprises (also known as BUMD) company in Kuningan Regency. Based on observations there is still a phenomenon that shows the achievement of employee performance at the company is still considered less than optimal. This can be illustrated from the results of employee performance appraisals from several divisions that are still below the minimum standards as shown in table 1 .

\section{Method}

Meyer and Allen (1991) defined organizational commitment as a moral responsibility to stay in the organization because of a reflection of one's feelings towards the organization. According to Steers (1977) Commitment is influenced by three factors, namely: personal characteristics, job characteristics and work experience. There are three components to the organizational commitment model (Meyer, et al, 1991; Luthans et al, 2011; Newstrom, 2011), namely:

a. Affective Commitment

Affective commitment is the desire to remain a member of the organization because of the emotional attachment and involvement of the organization. Employees stay in the organization because of their will. As emotional reasons (emotion based) it can be in the form of feelings of friendship, company climate and culture, and feelings of pleasure when completing work tasks.

b. Continuance Commitment

Continuance commitment is the desire to remain a member of the organization because of concern for the costs associated with leaving it. Employees stay in the organization because they need it. This is a cost based reason to remain. This includes salaries, 
benefits, promotions, time, effort, and economic and social losses that will occur when employees leave the company.

c. Normative Commitment

Normative commitment is a desire to remain a member of the organization because it feels like an obligation. Employees stay in the organization because they are supposed to. This is an obligation based to remain in the organization including feelings of gratitude to superiors, colleagues or larger companies.

In Islam, every Muslim is required to be committed to his organizational life with a demand that all forms of growth and material development must be demonstrated for the sake of justice, truth and increased spiritual devotion both for the organization and for himself as a form of responsibility as a caliph on earth (Jamil, 2007). Commitment in carrying out obligations and staying away from the prohibitions of Allah SWT is a manifestation of human commitment as God's creatures. Commitment is described in the Word of Allah SWT in Surat Alfath verse 10, which means:

"For those who pledge allegiance to you, they promise loyalty to Allah. Allah's hand is on their hands, then whoever breaks his promise will undoubtedly result in him breaking that promise will happen to himself and whoever keeps his promise to Allah, Allah will give him a great reward".

Strong persistence (belief) in organizational members will encourage members of the organization to remain consistent and responsible both physically and mentally in carrying out contracts with the organization as a form of commitment to Allah SWT. This is expressed in intentions, and work is a consequence of intention and every intention must be based on sincerity (Albukhori in Ahmad, 2009). Islam views commitment as the ability to carry out the mandate that is carried out to be accounted for at a later date. According to Jamil (2007), responsibility is always related to the concept of trust, the issue of trust is the result of transactions with Allah SWT. Based on Ahmad (2009), commitment is described in the AlQur'an in several verses (2: 139 and 98: 5). This is expressed in intention, and work is a consequence of intention (Al-Bukhari) where work is a consequence of intention, and every intention must be based on sincerity.

\subsection{Thinking Framework and Hypothesis}

High commitment to employees can improve the performance and smoothness of the production process. Employees with high commitment will show high performance as well. Hashim (2010) stated that human resources in an Islamic perspective are closely and significantly related to organizational commitment. The research paradigm is:

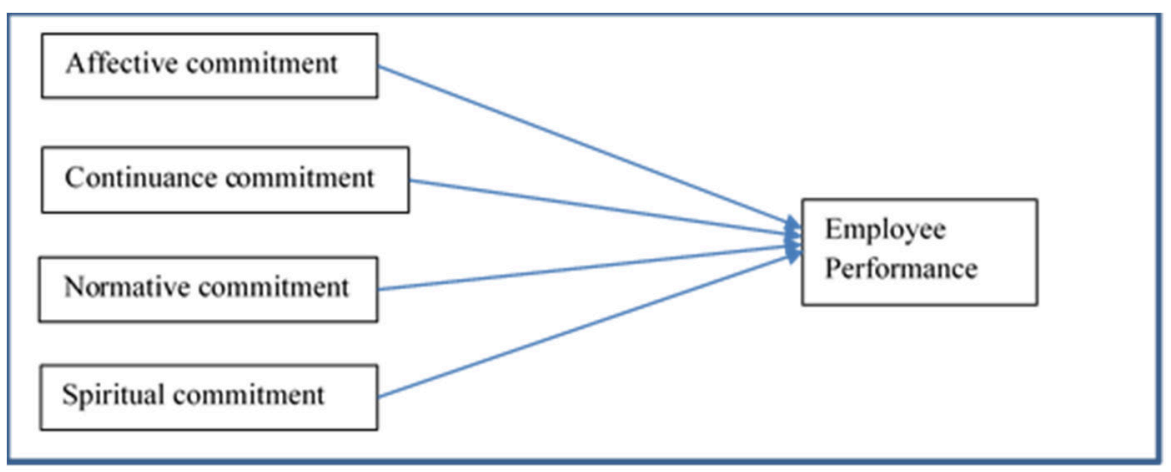

Fig 1. Research paradigm 
The hypothesis proposed in this study are:

H1 Affective commitment has a positive and significant effect on employee performance $\mathrm{H} 2$ Continuance commitment has a positive and significant effect on employee performance H3 Normative commitment has a positive and significant effect on employee performance H4 Spiritual commitment has a positive and significant effect on employee performance

The research method used is descriptive and verification methods. The dependent variable is employee performance $(\mathrm{Y})$ and the independent variable is organizational commitment consisting of affective commitment (X1), continuous commitment (X2), normative commitment (X3) and spiritual commitment (X4). The population in this study were employees of PDAM Tirta Kamuning Kab. Kuningan numbered 185 people. The sample technique used is simple random sampling (Sugiono, 2014) by determining the number of samples using the Slovin formula (Sugiono, 2014). Based on the calculation of Slovin the number of samples in this study were 126 people with a margin of error (e) of $5 \%$.

The analysis technique used is multiple linear regression analysis by first testing the validity and reliability and testing the classical assumptions using SPSS software. Hypothesis testing used is the $t$ test and $F$ test and to determine the magnitude of the partial effect of the independent variable on the dependent, the coefficient of determination is calculated.

\section{Result and Discussion}

After testing the validity and reliability of the instrument and fulfilling the requirements of the classical assumption test results, the authors conducted multiple linear regression analysis through SPSS software and obtained the following calculation results:

Table 2. Results of Multiple Linear Regression Test

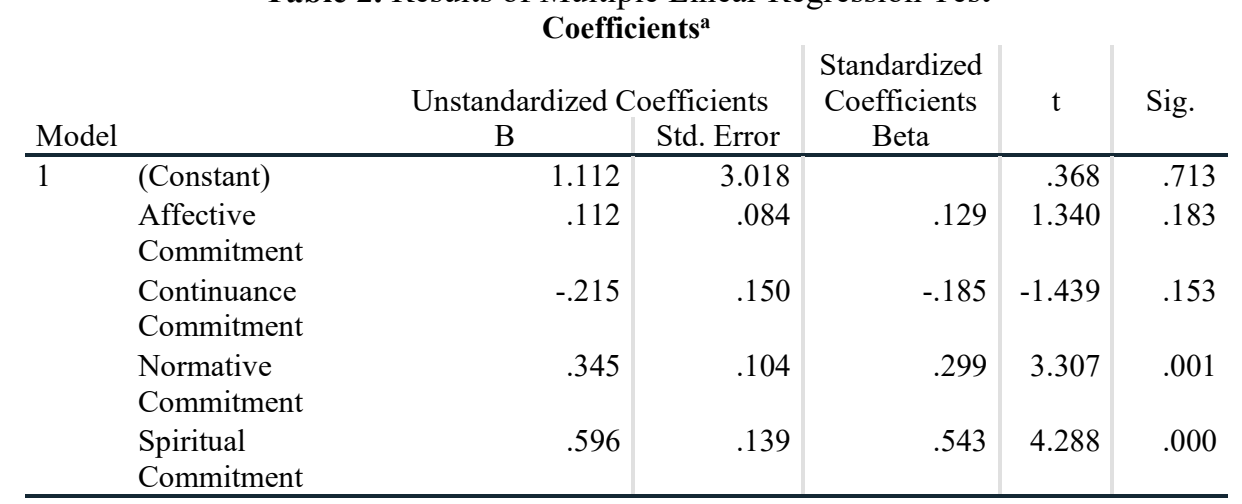

a. Dependent Variable: Employee Performance

Based on this table, the regression equation is obtained as follows:

$$
\mathrm{Y}=1.112+0.112 \mathrm{X} 1+(-0.215) \mathrm{X} 2+0.345 \mathrm{X} 3+0.596 \mathrm{X} 4
$$

The meaning of this equation is if the values of X1, X2, X3, and X4 are zero, then the value of the variable $\mathrm{Y}$ (Employee Performance) is 1,112 units. The coefficient of affective commitment, normative commitment and spiritual commitment is positive, meaning that it has 
a positive effect on employee performance. From the table above, it can be seen that religious commitment has the greatest influence on employee performance as evidenced by the Beta value of 0.543 or an effect on performance of $29.4 \%$.

\section{Hypothesis Test}

Based on table 1, it can be seen that the results of the partial hypothesis test are as follows:

H1 Affective commitment has no significant effect on employee performance

Based on the results of the $t$ test, it was found that the sig value $>0.05$ was 0.183 , indicating that the hypothesis was rejected.

H2 Continuous commitment has a negative but insignificant effect on employee performance.

H3 Normative commitment has a positive and significant effect on employee performance. Based on the results of the $t$ test, the sig value $<0.05$ is obtained, which is equal to 0.001 with a positive coefficient, indicating that the hypothesis is accepted.

H4 Spiritual commitment has a positive and significant effect on employee performance Based on the results of the $t$ test, the sig value $<0.05$ is obtained, which is equal to 0.000 with a positive coefficient, indicating that the hypothesis is accepted.

Table 3. ANOVAa

\begin{tabular}{|c|c|c|c|c|c|c|}
\hline Model & & Sum of Squares & Df & Mean Square & $\mathrm{F}$ & Sig. \\
\hline \multirow{3}{*}{1} & Regression & 717.239 & 4 & 179.310 & 24.718 & $.000^{\mathrm{b}}$ \\
\hline & Residual & 877.753 & 121 & 7.254 & & \\
\hline & Total & 1594.992 & 125 & & & \\
\hline
\end{tabular}

Based on table 2, it can be seen that the results of the $\mathrm{F}$ test show the sig value $<0.05$, which is equal to 0,000 , which means that $\mathrm{X} 1, \mathrm{X} 2, \mathrm{X} 3$, and $\mathrm{X} 4$ simultaneously have a positive and significant effect on employee performance.

\section{Coefficient of Determination}

\begin{tabular}{ll|l|c|c} 
& & \multicolumn{2}{c}{ Table 4. Model Summary } \\
Adjusted R \\
Model & $\mathrm{R}$ & R Square & Square & $\begin{array}{c}\text { Std. Error of the } \\
\text { Estimate }\end{array}$ \\
\hline 1 & $.671^{\mathrm{a}}$ & .450 & .431 & 2.69335 \\
\hline
\end{tabular}

a. Predictors: (Constant), Spiritual Commitment, Normative Commitment,

Affective Commitment, Continuance Commitment

The results of the coefficient of determination show the amount of influence with the variable affective commitment (X1), continuance commitment (X2), normative commitment (X3), and spiritual commitment (X4) on employee performance (Y) of 0.450 or $45 \%$ and the remaining $55 \%$ is influenced by others variables who were not examined in this study.

This study is different from research on organizational commitment in the conventional view, because it provides a new approach, by adding a variable spiritual commitment as a component of organizational commitment. Spiritual commitment consists of the concepts of trust and sincerity (Ahmad, 2009; Jamil 2007). The results show a significant difference 
between the influence of spiritual commitments and other commitments. Spiritual commitment has the greatest influence on performance with a positive and significant coefficient value. This is the basis that through high spiritual commitment, employees will have higher performance as well. This is relevant to the results of previous studies which found that organizational commitment is highly and significantly correlated with the Islamic approach to Human Resource Management (Hashim 2010; Bhatnagar, 2007; Edgar and Geare, 2004; Joiner and Bakalis, 2006; Lok and Crawford, 2001; Yousef., 1999, 2001).

However, the results of the calculation of the $\mathrm{F}$ test show that the 4 components of commitment studied have a significant effect on employee performance, this is in accordance with the results of previous studies which show that organizational commitment has a positive and significant effect on employee performance (Fauzan, et.al 2014; Suliman, et al. .al 2000; Shore, et.al 1995; Paramita, et.al 2020; Streers, 1977). The organizational commitment model produced in this study can be described as follows:

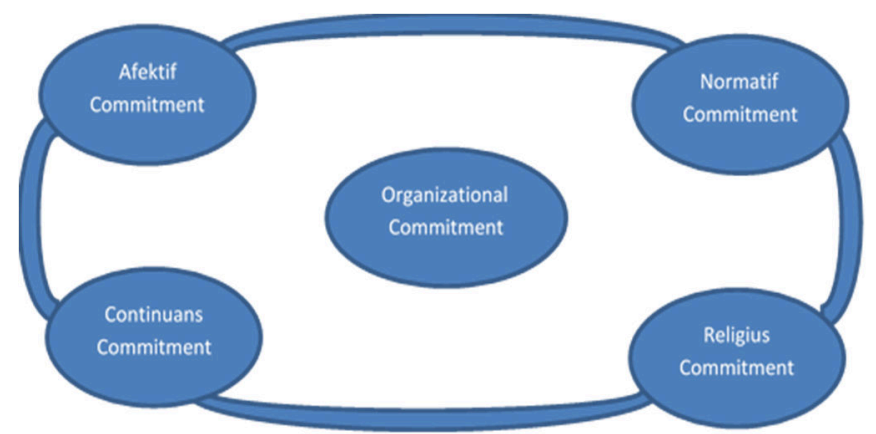

Fig 2. Organizational Commitment Model

\section{Conclusion}

a. Affective commitment has no significant effect on employee performance

b. Continuous commitment has a negative but not significant effect on performance

c. Normative commitment has a positive and significant effect on employee performance

d. Spiritual commitment has a positive and significant effect on employee performance

\section{References}

[1] Alfi Hasan Fauzan, Sumiyati. “ Pengaruh Komitmen Organisasi terhadap Kinerja Karyawan pt. Bank mandiri. Tbk. Area cirebon. 2014

[2] Alwiyah Jamil. (2007). "Pengaruh Etika Kerja Islam terhadap Sikap-Sikap pada Perubahan Organisasi: Komitmen Organisasional Sebagai Mediator"

[3] Bhatnagar, J. (2007), "Predictors of organizational commitment in India: strategic HR roles, organizational learning capability and psychological empowerment", Human Resource Management International Digest, Vol. 18 No. 3, pp. 1782-812.

[4] Edgar, F. and Geare, A. (2004), "HRM practice and employee attitudes: different measures different results", Personnel Review, Vol. 34 No. 5, pp. 534-49. 
[5] Erna Paramita, Prihatin Lumbanraja, Yeni Absah "The Influence of Organizational Culture and Organizational Commitment on Employee Performance and Job Satisfaction as a Moderating Variable at PT. Bank Mandiri (Persero), Tbk" International Journal of Research and Review Vol.7; Issue: 3; March 2020

[6] Joiner, T. and Bakalis, S. (2006), "The antecedents of organizational commitment: the case of Australian casual academics", International Journal of Educational Management, Vol. 20 No. 6, pp. 439-52.

[7] Junaidah Hashim, (2010),"Human resource management practices on organizational commitment", Personnel Review, Vol. 39 Iss 6 pp. $785-799$

[8] Lok, P. and Crawford, J. (2001), "Antecedents of organizational commitment and the mediating role of job satisfaction", Journal of Managerial Psychology, Vol. 16 No. 8, pp. 594-613.

[9] Luthans, F., \& Peterson, S. J. (2002). Employee engagement and manager self-efficacy:Implications for managerial effectiveness and development. Journal of Management Development

[10] Mary A. Konovsky, S Douglas Pugh, “Cityzenship Behaviour and Social Exchange” Academy of Managment Journal Vol 37, No 3, 656 - 6691994

[11] Meyer \& Allen, 1991, A three-component conceptualization of organizational commitment The University of Western Ontario Canada

[12] Meyer \& Allen, 1991, A three-component conceptualization of organizational commitment The University of Western Ontario Canada

[13] Newstrom, John W. 2011. Organizational Behavior: Human Behavior at Work. Newyork-America: McGraw-Hill Education

[14] Schemerson, Jr.,John R.,James G. Hunt, Richard N. Orborn, and Mary Uhl-Bien. (2011). Organizational Behavior. JohnWiley \& Sons, Inc. new Jersey.

[15] Shore, L.M., Barksdale, K., \& Shore, T.H. "Managerial perceptions of employee commitment to the organization" Academy of Management Journal 1995

[16] Steers, R.M. "Antecedents and Outcomes of Organisational Commitment" Administrative Science Quarterly, 22, 46-56. (1977)

[17] Stephen P. Robbins, "Organizational Behaviour" Pearson. Australia. 2008

[18] Suliman, A. and Iles, P. "Is continuance commitment beneficial to organisations? Commitmentperformance relationship: a new look", Journal of Managerial Psychology, 15, 5, pp.407-426 2000

[19] Yousef, D. (1999), "Organizational commitment and job satisfaction as predictors of attitudes toward organizational change in a non-Western setting", Personnel Review, Vol. 29 No. 5, pp. $567-$ 92.

[20] Yousef, D. (2001), "Islamic work ethic - a moderator between organizational commitment and job satisfaction in a cross-cultural context", Personnel Review, Vol. 30 No. 2, pp. 152-69. 